Asia-Pacific Business Review, January-June 2005, 1 (1), 18-25.

\title{
Impact of Family Values and Gender on Transformational Leadership
}

\author{
Ishita Ganguli and Venkat R. Krishnan
}

\begin{abstract}
This study looks at the relationship between family values, gender norms, and transformational leadership, using a sample of 56 managersubordinate pairs from five organizations with headquarters in eastern India. Schwartz value survey, Bem Sex Role Inventory, and Multifactor Leadership Questionnaire were used. The findings show that managers whose parents gave importance to benevolence values would possess feminine characteristics. However, neither benevolence values nor femininity was related to transformational leadership. Nevertheless, another significant finding that emerged from this study was the positive relationship between stimulation values and transformational leadership. This indicated that parents who gave importance to stimulation values are likely to have their children becoming transformational leaders.
\end{abstract}

Change has become the order of the day and for organizations to keep their competitive edge in this global era, managing change has become a very important agenda. In this context, the concept of leadership has taken a crucial position in organizations. Moreover, among the different styles of leadership, transformational leadership has taken a distinct position in today's complex organizational scenario to be the most suitable form.

The concept of transformational leadership was first conceived by Burns (1978) and the concept was extended by Bass (1985). Transformational leadership has gained a lot of importance over the past few decades. Burns defined transformational leaders as those who motivate followers to work for transcendental goals rather than for immediate self-interest and arouse in them higher-level needs for self-actualisation. Transformational leaders also increase productivity and performance (Bass, 1985). They identify the true needs of followers and help them achieve their desired goals thereby lifting themselves to a higher level. Transformational leadership depends on personality characteristics like high need for power and activity inhibition (House, Spangler, \& Woycke, 1991).

Transformational leaders hold certain values, which they inculcate in their followers (Krishnan, 2002). Values are concepts or beliefs that act as guiding principles in life. Family values are those that are inculcated from parents. Kuhnert and Lewis (1987) used a constructive/developmental theory to explain how critical personality differences in leaders lead to either transactional or transformational leadership. A three-stage developmental model was proposed. Constructive personality theories hold that people vary in the ways in which they construct or organize experiences about themselves and their social and 
interpersonal environments. So family values inherited by the person who grows up to be a transformational leader would be unique.

Gender norms are defined as the degree to which one sees oneself as masculine or feminine. There are not much differences in traits or temperaments between the sexes because of biological factors. Rather, they result from differences in socialization and the cultural expectations or norms held for each sex (Stets \& Burke, 2000). Therefore, the socialization process of individuals helps in determining whether they see themselves as masculine and feminine.

Transformational leaders would have their own set of values some of which might have been inherited from their families and they would also have a gender norm. In this study, we tried to see the effect of family values and a person's gender characteristics on transformational leadership. In today's organizations where leadership is the key determinant of outcomes, managers would find this information useful and may apply it in a variety of areas starting from recruitment to counselling.

\section{Theory and Hypotheses}

\section{Family Values}

Values play an important role in all institutional settings. They are standards that are largely derived, learned, and internalised from the society. Schwartz and Bilsky (1987) said that values are (a) concepts or beliefs, (b) about desirable end states or behaviours, (c) that transcend specific situations, (d) guide selection or evaluation of behaviour and events, and (e) are ordered by relative importance. Rokeach (1979) mentioned that our approach to the conceptualisation and measurement of values has been most influenced by William's notion of values as standards of conduct and by Kluckhon's definition of values as conceptions of the desirable means and ends of action. A set of rank-ordered values is a value system.

Rokeach defined a value system as an enduring organization of beliefs concerning preferable modes of conduct or end-states of existence along a continuum of relative importance. The Rokeach Value Survey contains a list of both terminal and instrumental values among which some are honesty, being obedient, responsible, helpful, etc.

Impact of values. Values affect a wide range of variables. Ravlin and Meglino (1987) showed that values related to work affect the perception as well as the decision making of people. Schwartz and Inbar-Saban (1988) showed that values also affect the weight loss in an individual. Successful weight losers differed from the unsuccessful in valuing wisdom more than happiness. Studies have shown that organizational commitment and conservatism are affected by values (Feather, 1979; Meglino, Ravlin, \& Adkins, 1989). Homer and Kahle (1988) found that people who have more internally oriented and less externally oriented value structure liked natural food more than other people. Thomas, Dickson, and Bliese (2001) showed that the two-value orientations of power and influence predict leadership effectiveness. Values change either as a result of (1) changes in self-conceptions or definitions of the self or because of (2) increases in self-awareness-about hypocrisies, inconsistencies or contradictions between self-conceptions or self-ideals on the one hand, and one's values, related attitudes, and behaviours, on the other (Leff, 1978).

Motivational domains of values. Schwartz and Bilsky (1987) grouped values with respect to the motivational goal that they expressed. They derived 10 motivationally distinct, broad value domains from three universal requirements of human condition. They 
characterized each value by describing its central motivational goal. Taking cultures together, men and women also share the same motivational organization of broad values i.e. they perceive the same motivational domains and congruencies and conflicts among the different values (Struch, Schwartz, \& Van der Kloot, 2002).

Causes of values. Looking at the causes of values might show the process of socialization in which the family plays an important role. Understanding individual in the context of the family is very old, starting with Sigmund Freud's profound preoccupation with the influence of the family in early childhood development (Freud, 1965). Szapocznik and Kurtines (1993) introduced the concept of the embeddedness of the individual within the context of the family within the context of the culture. Value can be transmitted from the parents to their offspring. The term value transmission was usually used to mean the socialization of values in institutions, predominantly in the family. There is value congruence between parents and children (Boehnke, 2001). Knafo and Schwartz (2001) examined the impacts of immigration on parent-adolescent value similarity, consistency of parents' value messages, and the value transmission process. They discussed why group versus withinfamily analysis could yield contradictory results and why findings depend on the specific values studied.

\section{Gender Norms}

There are not much differences in traits or temperaments between the sexes on account of biological factors. Rather, they result from differences in socialization and the cultural expectations or norms held for each sex. Societal members decide what being male or female means, like dominant or passive, brave or emotional (Stets \& Burke, 2000). Gender is a vast area having concepts like gender identity, gender roles, gender stereotypes, and gender attitudes. Femininity and masculinity or one's gender identity refers to the degree persons see themselves as masculine or feminine given what it means to be a man or woman in a society. Stets and Burke described gender roles as shared expectations of one's behaviour given one's gender. They also defined gender stereotypes to be shared views of personality traits often tied to one's gender such as instrumentality in men and expressiveness in women. Gender attitudes are the views of others or situations commonly associated with one's gender such as men thinking in terms of justice and women thinking in terms of care. Norms define the socially appropriate way to respond in the group - the normal course of action-and the types of actions that should be avoided if possible (Sorrels \& Kelly, 1984).

Influence of gender. Mellor (1995) in a study examined the influence of gender features of local union office on women and men's ratings regarding participation in local activities and found that women's participation was higher than men. Shenhav (1992) in a study examined the effects of worker's gender and race on their entry into public and private organizations. Results showed that women have promotion advantages in the private sector. Brass (1985) investigated the interaction patterns of men and women and the relationship of those patterns to (1) perceptions of influence and (2) promotions to supervisory positions. Results showed that women are less influential than men and are not well integrated into the men's networks in organizations. It was seen that women who identified with feminine sex role characterized by nurturance, accommodating, warmth and eagerness to sooth hurt feelings have lower career achievement in comparison to those who identify with a masculine sex role. Again, masculine traits are generally taken as assertiveness and independence (Noe, 1988). Mothers bond with the daughters to develop femininity in them and fathers with their sons to develop masculinity (Stets \& Burke, 2000). 
Gender and leadership. Dobbins and Platz (1986) showed that male and female leaders exhibited equal amounts of initiating structure and consideration and had equally satisfied subordinates and only under laboratory settings, the male leaders were rated as more effective. Carbonnel (1984) in a study showed that when a masculine task was given, women did not take up leadership role but when it was feminine in nature they took it up. Eagly, Makhijani and Klonsky (1992) showed that women in leadership positions were devalued relative to their male counterparts when leadership was carried out in stereotypically masculine styles like autocratic or directive. The devaluation of women was greater when leaders occupied male-dominated roles. Eagly, Karau, and Makhijani (1995) showed that women were more effective than men in leadership roles that were defined in less masculine terms. Eagly and Johnson (1990) showed that women tend to adopt a more democratic or participative style of leadership and less autocratic or directive style than did men. Hare, Koenigs, and Hare (1997) provided evidence of the relationship between expectations for the values for effective performance by female and male managers and their actual values. The differences in the temperament of men and women results from differences in socialization and the cultural expectations held for each sex (Stets \& Burke, 2000). Powell and Butterfield (1979) showed that the application of the Bem Sex Role Inventory (BSRI) on a set of subjects revealed that a good manager was described in masculine terms.

\section{Family Values and Gender Norms}

Values are transmitted from parents to children in families while bringing up the children. Parents try to inculcate their values in their children. Some values are related to gender i.e. masculinity or femininity. The behaviour of female leaders, compared with that of male leaders, is more interpersonally oriented, democratic, and transformational. In contrast, the behaviour of male leaders, compared with that of female leaders, is more task-oriented and autocratic. Eagly and Johannesen-Schmidt (2001) showed that the female managers, more than the male managers, (a) manifest attributes that motivate their followers to feel respect and pride by their association with them, (b) show optimism and excitement about future goals, and (c) attempt to develop and mentor followers and attend to their individual needs. All these attributes can be thought to be same as being helpful and responsible because they help followers to motivate and take the responsibility to make the followers attain their goals. Therefore:

Hypothesis 1. Importance given by family to benevolence values would be positively related to femininity.

\section{Transformational Leadership}

Transformational leaders attempt to raise the needs of followers and promote dramatic changes of individuals, groups, and organizations (Burns, 1978). They identify and fulfil the true needs of followers and raise them to a higher level. Transformational leaders articulate a realistic vision of the future that can be shared, stimulate subordinates intellectually, and pay attention to the differences among the subordinates (Bass, 1985). Moreover, Bass also mentioned that transformational leaders motivate followers to do more than originally expected. Such a transformation could be achieved by (a) raising the awareness of the value of designated outcomes, (b) getting followers to transcend their own self-interests, or (c) altering or expanding follower's needs on Maslow's hierarchy of needs. Transformational leadership consists of five factors-attributed charisma i.e. exhibiting charisma which helps the followers identify with the leaders' aspirations and emulate them, idealized influence i.e. serving as a charismatic role model to the followers, inspirational motivation i.e. arousal and 
heightening of motivation among the followers, intellectual stimulation i.e. stimulating followers to be creative and innovative by challenging the status quo, and individualized consideration i.e. attending to and supporting the needs of the followers.

Characteristics of transformational leaders. Bass (1985) suggested that there were personality traits, which differentiated transformational leaders from non-transformational leaders (Atwater \& Yammarino, 1993). Behling and Mcfillen (1996) mentioned the six important attributes of leader behaviour as: display empathy, dramatize the mission, project self-assurance, enhance the leader's image, assure followers of their competencies, provide followers with opportunities to experience success. Tichy and Devanna (1986) saw being courageous and value-driven as major factors in leader success. Burns (1978) wrote of some leaders' 'fanatical conviction' (p. 203). Bass (1985) pointed out that dedication can become 'stubborn insensitivity to others...coldness and arrogance' (p. 50) and Tichy and Devanna (1986) focused on values as a key component of the leader's vision (p. 133), and indicated that the vision 'becomes like the holy grail of the crusades and motivates people to overcome themselves' (p. 142). Transformational leaders facilitate performance beyond ordinary expectations as they transmit a sense of mission, stimulate learning experiences, and arouse new ways of thinking. Kirkpatrick and Locke (1991) mentioned that the study of leader traits has a long and controversial history. While research shows that the possession of certain traits alone does not guarantee leadership success, there is evidence that effective leaders are different from other people in certain key respects. Key leader traits include: drive (a broad term which includes achievement, motivation, ambition, energy, tenacity, and initiative); leadership motivation (the desire to lead but not to seek power as an end in itself); honesty and integrity; self-confidence (which is associated with emotional stability); cognitive ability; and knowledge of the business.

\section{Family Values and Transformational Leadership}

Krishnan (2001) found that transformational leaders give high priority to "world at peace" and "responsible" and low priority to "world of beauty", "national security," and being "intellectual" and "cheerful." He also showed that the leaders give more importance to values concerning others than those concerning themselves. Both Bass (1985) and Burns (1978) indicated that transformational leader operate out of deeply held personal value system, which include justice and integrity and are referred to as end values. Kuhnert and Lewis (1987) said that transformational leaders act according to the end values like integrity, self-respect, and equality that they integrate into the work group. It has been seen that values in an individual develop through a process of socialization in which family plays an important role. A leader possesses certain values some of which have been inculcated from his family. Therefore:

Hypothesis 2. Importance given by family to benevolence values would be positively related to transformational leadership.

Hypothesis 3. Importance given by family to stimulation values would be positively related to transformational leadership.

\section{Gender Norms and Transformational Leadership}

Carless (1998) found that females were rated higher on transformational leadership behaviours than males. Females were reported higher on subscales of charisma and individualized consideration. Carless found in this study that female managers were more likely than male managers to report that they took an interest in the personal needs of their 
staff, encouraged self-development, used participative decision making, gave feedback, and publicly recognized team achievements. In summary, female managers use more interpersonal-oriented leadership behaviours compared to male managers. From the gender point of view it has been seen that women have a feminine style of leadership, which is characterized by caring and nurturance and men adopt a masculine kind of leadership, which is dominating and task-oriented (Eagly, Makhijani, \& Klonsky, 1992). Yammarino, Dubinsky, Comer, and Jolson (1997) showed that female leaders form unique relationships with each of their subordinates. Women engage in an interpersonal process where each leader and follower exert mutual control and influence over one another and are mutually dependent. Ross and Offermann (1997) showed that transformational leadership is positively related to levels of pragmatism, nurturance, and feminine attributes and negatively related to criticalness and aggression. Maher (1997) showed that female subjects associate transformational leadership more with women than with men suggesting that stereotypes play a role. Eagly and Johannesen-Schmidt (2001) showed that women adopt female gender roles and these could be assessed in the scales of individualized consideration and inspirational motivation. The leaders are encouraging and supportive. They show optimism and excitement about the future that are assessed by the inspirational motivation subscale. Therefore:

Hypothesis 4. Femininity would be positively related to transformational leadership.

\section{Method}

Data was collected from 56 pairs of managers and their subordinates working in five manufacturing organizations with headquarters in eastern India. They were mainly into production of large vehicles, food products, aluminium, and cement. The age group of the subjects varied from 25 years to 65 years. In the sample of managers, 52 were males, 4 were females, and in subordinates, 51 were males and 5 were females. 27 managers were brought up in cities, 14 in towns, 11 in villages; 30 had been brought up in nuclear families and 26 in joint families. They had spent a considerable part of their life with their parents. The managers were given the value and gender questionnaire and the subordinates were given the transformational leadership questionnaire. The first variable was measured by using the Schwartz Value Questionnaire. This was administered on the managers, who were asked to rate each value in terms of its importance to their parents. Next, the variable gender-norms was measured using the BSRI. The third variable i.e. transformational leadership was measured using Multifactor Leadership Questionnaire (MLQ) that was administered on the subordinates.

\section{Results}

The Schwartz value questionnaire has 56 questions or items on values. These items were grouped into 10 groups of values as had been done by Schwartz and Bilsky (1987). These 10 groups are tradition, security, power, conformity, achievement, hedonism, benevolence, stimulation, universalism, and self-direction. A reliability test was conducted after which security, tradition, power, and hedonism were dropped as they showed Cronbach alpha values less than 0.6 . Table 1 presents the results of a correlation analysis done among the six value domains, masculinity, femininity, and transformational leadership.

Femininity was significantly positively related to benevolence. So Hypothesis 1 was supported. However, benevolence was not related to transformational leadership. So Hypothesis 2 was not supported. Stimulation was significantly positively related to 
transformational leadership. So Hypothesis 3 was supported. There was no significant correlation between femininity and transformational leadership. So Hypothesis 4 was not supported. A regression analysis was done taking transformational leadership as the dependent variable. The independent variables were masculinity, femininity, and the six values--universalism, self-direction, benevolence, stimulation, conformity, and achievement. The results showed that the best predictor of transformational leadership were the stimulation values.

\section{Discussion}

With the growing complexity of the environment, business organizations are facing constant challenges and seek to find leaders who can smoothly transform their followers thereby turning around organizations. It has been seen from research that parents transmit family values to their progenies over generations. Therefore, we have tried to establish a link between these family values, gender norms, and transformational leadership. Results of this study show that inculcating benevolence values is positively related to femininity and inculcating stimulation values enhances transformational leadership.

This study shows that families nurturing benevolent values like being responsible, helpful, honest, etc. would bring up their children with feminine norms. Femininity means a person will be helpful, conscientious, reliable, truthful, adaptable, friendly, etc. Looking at anthropological sciences we see that right from the beginning of human civilization males were typically people who used to go out and hunt and females stayed at home looking after the household and the family. As a result, over generations, genetically as well as biologically, males and females were characterized by masculine and feminine characteristics respectively. However, in modern society there is no need for hunting and collection of food the way it was required in the pre-historic society. In today's society, attributes that are more important are human and social skills, which are feminine in nature. Therefore, parents holding benevolence values will facilitate the development of femininity in their children.

However, no support is obtained for relationship between benevolence and transformational leadership. This implies that families who pass on benevolent values do not necessarily produce leaders who are transformational. This may imply that in the real world transformational leaders might not necessarily possess values which are benevolent in nature. The study also does not show femininity to be positively related to transformational leadership. Femininity might not be associated with transformational leadership attributes, probably because in the work front, subordinates do not like too much individual attention and take it as interference. Moreover the leaders might not inspire them enough due to lack of proper need identification on their part. Being too much caring and sincere might portray one as being inefficient and might be taken as intruding into the other person's personal sphere. Therefore, the femininity of a manager might not appeal to the subordinates. On the contrary, probably it is important for managers to exhibit and practice values governed by the motivational goal of stimulation to become transformational leaders. Stimulation values include excitement, novelty, and challenge in life. A person governed by these will be selfconfident and self-sufficient and will be able to keep others motivated, and to stimulate and excite them in pursuit of their work.

\section{Limitations}

Our sample of 56 manager-subordinate pairs, was probably too small to yield more significant findings. Another point to be noted is that the mangers were asked to fill up their 
values, which they had inherited, from their parents. So possibly, they may have forgotten many of them or they may have developed many of their own values rather than sticking on to the ones passed on by their parents. The sample was restricted to the eastern part of India and not all over. Therefore, the values captured might be generalizable only to those living in the eastern part of the country. While doing the reliability tests, four of the value domains had Cronbach alpha less than 0.6, and we dropped them from the study.

\section{Conclusion}

Despite these limitations, this study has made some theoretical contributions. This study has shown that importance given by parents to stimulation values enhances transformational leadership of their children. Therefore, organizations can use this to identify the managers based on their value profile and background and place them in appropriate positions to carry out transformations. This can bring about a change in the business scenario and help organizations to keep their competitive edge by breeding more transformational leaders. 


\section{References}

Atwater, L. E., \&Yammarino, F. J. (1993). Personal attributes as predictors of superiors 'and subordinates' perceptions of military academy leadership. Human Relations, 46(5), 645.

Bass, B. M. (1985). Leadership and Performance Beyond Expectations, New York: Free Press.

Behling, O., \& Mcfillen, J. M. (1996). A syncretical model charismatic/transformational leadership. Group \& Organization Management, 21(2), 163-191.

Boehnke, K. (2001). Parent-offspring value transmission in a societal context (Suggestions for a Utopian research design-With empirical underpinnings). Journal of CrossCultural Psychology, 32(2), 241-255.

Brass, D. J. (1985). Men and women's networks: A study of interaction patterns and influence in an organization. Academy of Management Journal, 28, 327-343.

Burns, J .M. (1978). Leadership, New York: Harper \& Row.

Carbonnel, J. L. (1984). Sex roles and leadership revisited. Journal of Applied Psychology, 69(1), 44-49.

Carless, S. A. (1998). Gender differences in transformational leadership: An examination of superior, leader, and subordinate perspectives. Sex Roles, 39(11/12), 887-902.

Dobbins, G. H. \& Platz, S. J. (1988). Sex Differences in Leadership: How real are they? Academy of Management Review, 11(1), 118-127.

Eagly, A. H., \& Johnson, B. T. (1990). Gender and leadership style: A meta-analysis. Psychological Bulletin, 108(2), 233-256.

Eagly, A.H., \& Johannesen-Schmidt, M.C. (2001). The leadership styles of women and men. Journal of Social Issues, 57(4), 781-797.

Eagly, A. H., Karau, S. J., \& Makhijani, M. G. (1995). Gender and effectiveness of leaders: A meta-analysis. Psychological Bulletin, 117(1), 125-145.

Eagly, A. H., Makhijani, M. G., \& Klonsky, B.G. (1992). Gender and the evaluation of leaders: A meta-analysis. Psychological Bulletin, 111(1), 3-22.

Feather, N. T. (1979). Value correlates of conservatism. Journal of Personality and Social Psychology, 37, 1617-1630.

Freud, S. (1965). New introductory lectures. New York: Norton.

Hare, A. P., Koenigs, R. J., \& Hare, S. E. (1997). Perceptions of observed and model values of male and female managers. Journal of Organizational Behavior, 18, 437-447.

Homer, P. M., \& Kahle, L. R. (1988). A structural equation test of value-attitude behavior hierarchy. Journal of Personality and Social Psychology, 54: 638-646.

Kirpatrick, S. A., \& Locke, E. A. (1991). Leadership: Do traits matter? The Executive, 5(2), 48.

Knafo, A., \& Schwartz, S. H. (2001). Value socialization in families of Israeli-born and Soviet-born adolescents in Israel. Journal of Cross-Cultural Psychology, 32(2): 213228. 
Krishnan, V. R. (2002). Transformational leadership and value system congruence. International Journal of Value-Based Management, 15 (1), 19-33.

Krishnan, V. R. (2001). Value systems of transformational leaders. Leadership \& Organization Development Journal, 22 (3), 126-132.

Kuhnert, K.W., \& Lewis, P. (1987). Transactional and transformational leadership: A constructive/developmental analysis. Academy of Management Review, 12(4), 648657.

Leff, H. L. (1978). Experience, environment and human potential, New York: Oxford University.

Maher, K.J. (1997). Gender-related stereotypes of transformational and transactional leadership. Sex Roles, 37(3-4), 209-225.

Meglino, B. M., Ravlin, E. C., \& Adkins, C. L. (1989). A work values approach to corporate culture: A field test of the value congruence process and its relationship to individual outcomes. Journal of Applied Psychology, 74, 424-432.

Mellor, S. (1995). Gender composition and gender representation in local unions: Relationships between women's participation in local office and women's participation in local activities. Journal of Applied Psychology, 80(6), 706-720.

Noe, R. A. (1988). Women and mentoring: A review and research agenda. Academy of Management Review, 13(1), 65-78.

Ravlin, E. C., \& Meglino, B. M. (1987). Effect of values on perception and decision-making: A study of alternative work values measures. Journal of Applied Psychology, 72, 666673.

Rokeach, M. (1979). Understanding Human Values (Individual and Societal), New York: Free Press.

Ross, S. M., \& Offermann, L. R. (1997). Transformational leaders: Measurement of personality attributes and work group performance. Personality and Social Psychology Bulletin, 23, 1078-1086.

Schwartz, S. H., \& Bilsky, W. (1987). Toward a psychological structure of human values. Journal of Personality and Social Psychology, 53, 550-562

Schwartz, S. H., \& Inbar-Saban, N. (1988). Value self-confrontation as a method to aid in weight loss. Journal of Personality and Social Psychology, 54(3), 396-404.

Shenhav, Y. (1992). Entrance of blacks and women into management positions in scientific and engineering occupations: A longitudinal analysis. Academy of Management Journal, 35(4), 889-901.

Sorrels, J. P., \& Kelly, J. (1984). Conformity by omission. Personality and Social Psychology Bulletin, 10, 302-305.

Stets, J. E. \& Burke, P. J. (2000). Femininity/ Masculinity. In Borgatta, E. F. \& Montgomery, R. J. V. (Eds.), Encyclopedia of Sociology, Revised Edition, 997-1005, New York: Macmillan.

Szapocznik, J., \& Kurtines, W. M. (1993). Family Psychology and Cultural Diversity, American Psychologist, 48(4), 400-407.

Thomas, J. L., Dickson, M. W., \& Bliese, P. D. (2001). The Leadership Quarterly, 12,181196 
Tichy, N. M., \& Devanna, M. A. (1986). The Transformational Leader, New York: Wiley.

Yammarino, F.J., Dubinsky, A.J., Comer, L.B., \& Jolson, M.A. (1997). Women and transformational and contingent reward leadership: A multiple-levels-of-analysis perspective. Academy of Management Journal, 40(1), 205-222. 
Table 1

Correlations between Variables

\begin{tabular}{lrrrrrrrrrrr}
\hline$(\mathrm{N}=56)$ & $\mathrm{M}$ & S.D. & 1 & 2 & 3 & 4 & 5 & 6 & 7 & 8 & 9 \\
\hline 1. Universalism & 4.92 & .94 & $(.76)$ & & & & & & & & \\
2. Self-Direction & 5.10 & .85 & $* * * .65$ & $(.27)$ & & & & & & & \\
3. Benevolence & 5.21 & .79 & $* * * .56$ & $* * * .55$ & $(.72)$ & & & & & & \\
4. Stimulation & 3.84 & 1.38 & $* * * .46$ & $* * * .58$ & $* .32$ & $(.63)$ & & & & & \\
5. Conformity & 5.75 & .86 & $* * * .49$ & $* * * .54$ & $* * * .71$ & $\dagger .24$ & $(.61)$ & & & \\
6.Achievement & 5.15 & .89 & $* * .37$ & $* * * .73$ & $* * * .52$ & $* * .43$ & $* * * .56$ & $(.73)$ & & & \\
7. Masculinity & 4.97 & .64 & $* * * .47$ & $* * * .46$ & $* * .35$ & $\dagger .24$ & .36 & $* * .39$ & $(.81)$ & & \\
8. Femininity & 4.79 & .49 & .20 & .20 & $* * .35$ & .08 & $* * .41$ & $* .27$ & $* * * .55$ & $(.67)$ & \\
9. Transformational leadership & 2.64 & .67 & .15 & .19 & .18 & $* * .32$ & .12 & .09 & .05 & .07 & $(.77)$ \\
\hline
\end{tabular}

Cronbach alphas are in parentheses along the diagonal.

$\dagger=\mathrm{p}<.10 .^{*}=\mathrm{p}<.05 . * *=\mathrm{p}<.01 . * * *=\mathrm{p}<.001$. 